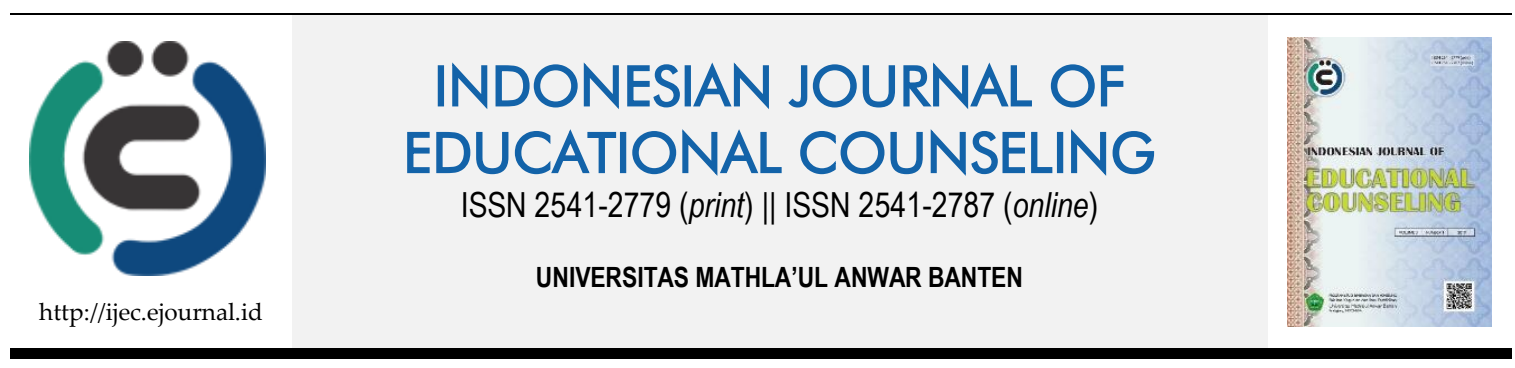

Research Based Article

\title{
Perbedaan Perilaku Agresif antara Siswa Aktif dengan Tidak Aktif dalam Kegiatan Ekstrakurikuler di SMPN 3 Way Jepara
}

\author{
Mudaim ${ }^{1}$, Eko Susanto ${ }^{2}$ \\ 1,2 Universitas Muhammadiyah Metro
}

\begin{tabular}{ll}
\hline Article History & ABSTRACT \\
\hline Received: 14.11.2018 & Aggressive behavior in adolescence is often shown with courageous attitude \\
Received in revised form: & against parents and teachers, mischief, crime and acts aggressively. This study \\
20.12.2018 & will look at differences in aggressive behavior between active and inactive \\
Accepted: 10.01.2019 & students in extracurricular activities in Junior high School 3 of Way Jepara. The \\
Available online: 25.01.2019 & method of this study is comparative research, where the instrument that used \\
& for collecting the data is scale of aggressive behavior. The population of this \\
& research is eighth and ninth grade students of Junior High School 3 of Way \\
& Jepara in East Lampung that consist of 180 students. The sample is took by \\
& Disproportionate Stratified random Sampling, then it is obtained the sample of \\
& 124 of active extra-curricular students, whereas, the non-active extra-curricular \\
& student that consist 56. Hypotheses assessment is conducted by independent \\
& sample t-test where obtain calculated value of aggressive behavior in 1.360 with \\
& significance level of 0.015. Because $p<0.05$ so Ho refused. There are some \\
differences between active students and inactive students of extra-curricular.
\end{tabular}

Keywords: Aggressive Behavior, Extracurricular.

DOI: 10.30653/001.201931.79

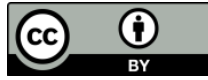

This is an open access article distributed under the terms of the Creative Commons Attribution 4.0 International License, which permits unrestricted use, distribution, and reproduction in any medium, provided the original work is properly cited. (๑) 2019 Mudaim, Eko Susanto.

\section{PENDAHULUAN}

Masa remaja merupakan masa yang sangat penting, sangat kritis dan sangat rentan, karena bila manusia melewati masa remajanya dengan kegagalannya, dimungkinkan akan menemukan kegagalan dalam perjalanan kehidupan pada masa berikutnya. Sebaliknya bila masa remaja itu diisi dengan penuh kesuksesan, kegiatan yang sangat produktif dan berhasil guna dalam rangka menyiapkan diri untuk memasuki tahapan kehidupan selanjutnya, dimungkinkan manusia itu akan mendapatkan kesuksesan dalam perjalanan hidupnya. Dengan demikian, masa remaja menjadi kunci sukses dalam memasuki tahapan kehidupan selanjutnya.

${ }^{1}$ Corresponding author's address: Program Studi Bimbingan dan Konseling FKIP Universitas Muhammadiyah Metro, Iringmulyo, Metro Timur, Kota Metro, Lampung 34381; Email: mudaim79@gmail.com 
Masa remaja berada dalam kisaran usia antara 11-19 tahun, adapula yang menyebut antara usia 11-24 tahun. Masa remaja merupakan masa transisi (masa peralihan) dari masa anak-anak menuju masa dewasa, yaitu saat manusia tidak mau lagi diperlakukan oleh lingkungan keluarga dan masyarakat sebagian anak-anak, tetapi dilihat dari pertumbuhan fisik, perkembangan psikis (kejiwaan), dan mentalnya belum menjukkan tanda-tanda dewasa. Pada masa ini (masa remaja), manusia banyak mengalami perubahan yang sangat fundamental dalam kehidupan baik perubahan fisik dan psikis (Majid, 2009). Remaja umumnya menghabiskan waktunya bersama teman-temannya, sehingga dalam pergaulan remaja cenderung mengikuti norma kelompok (to comform). Kuatnya pengaruh teman ini sering dianggap sebagai biang keladi dari tingkah laku remaja yang buruk (Sarwono, 2005). Hal ini didukung juga oleh tidak adanya pedoman yang kuat bagi remaja sehingga dalam menghadapi dampak negatif dari kemajuan pembangunan lebih nampak dari sikap dan perilakunya, dalam bentuk antara lain berupa sikap berani menentang orang tua dan guru, melakukan kenakalan dan kejahatan, bertindak agresif serta bentuk-bentuk perilaku agresif lainnya.

Beberapa faktor seperti keluarga, sekolah, dan teman sepermainan dianggap menjadi faktor penyebab perilaku kenakalan remaja. Banyak ahli percaya bahwa keluarga yang bermasalah merupakan penyebab utama dalam pembentukan masalah emosional pada anak yang dapat mengarah pada masalah sosial dalam jangka panjang (Siegel \& Welsh, 2011). Orang tua yang mengacuhkan atau tidak memenuhi kebutuhan anak dengan baik akan meningkatkan resiko keterlibatan anak dalam perilaku sosial yang tidak dapat diterima, seperti agresi dan masalah perilaku eksternal lain (Verlaan \& Schwartzman, 2002).

Baron dan Richarson (dalam Krahe, 2005) mengatakan bahwa agresif adalah segala bentuk perilaku yang dimaksudkan untuk menyakiti atau melukai makhluk hidup lain yang terdorong untuk menghindari perlakuan itu. Myers (2002) menjelaskan bahwa agresi merupakan perilaku fisik maupun verbal yang diniatkan untuk melukai obyek yang menjadi sasaran agresi. Secara umum, agresi adalah tanggapan yang mampu memberikan stimulus merugikan atau merusak terhadap organisme lain.

Schneiders (1991) menguraikan bahwa perilaku agresif dibentuk dari empat aspek: 1) pertahanan diri dengan cara menyerang, baik untuk menyerang terhadap benda maupun manusia, yaitu kecenderungan untuk melampiaskan keinginannya dan perasaan yang tidak nyaman ataupun tidak puas pada lingkungan di sekitarnya dengan melakukan penyerangan terhadap orang lain atau benda di sekitarnya; 2 ) superioritas, yaitu perilaku atau sikap individu yang menganggap dirinya lebih baik dari orang lain; 3) egosentris perilaku atau sikap individu yang cenderung mengutamakan kepentingan pribadi tanpa memperhatikan kepentingan orang lain; dan 4) perlawanan disiplin yaitu tindakan individu yang melanggar aturan demi mencapai kesenangan pribadi.

Dari uraian tersebut di atas maka dapat disimpulkan bahwa aspek perilaku agresif yaitu pertahanan diri dengan cara menyerang, superioritas, egosentris, perlawanan disiplin, survival dan otoriter.

Munculnya perilaku agresif salah satunya karena remaja tidak memanfaatkan waktu luang secara baik. Kegiatan di masa remaja sering hanya berkisar pada kegiatan sekolah dan seputar usaha menyelesaikan urusan di rumah, selain urusan tersebut remaja memiliki banyak waktu luang. Waktu luang tanpa kegiatan terlalu banyak akan 
menimbulkan gagasan untuk mengisi waktu luang dengan berbagai bentuk kegiatan. Apabila remaja melakukan kegiatan yang positif tentu tidak akan menimbulkan masalah. Namun, jika waktu luang tersebut digunakan untuk melakukan kegiatan yang negatif maka lingkungan dapat terganggu.

Pengisian waktu luang dengan baik dengan cara yang sesuai dengan umur remaja, masih merupakan masalah bagi kebanyakan remaja. Kebosanan, segan untuk melakukan apa saja merupakan fenomena yang sering kita jumpai (Monks, 2002). Masa remaja merupakan masa belajar di sekolah. Selama menghabiskan waktu di sekolah, remaja sedang mengisi waktu dengan kegiatan positif. Namun pada kenyataannya, waktu luang di luar jam sekolah justru lebih banyak dibandingkan dengan jam sekolah. Hal tersebut memberi peluang kepada remaja salah bergaul dan melakukan kegiatan-kegiatan negatif sehingga terjebak pada kenakalan remaja.

Sekolah sebagai instansi yang selama ini dipercaya untuk mendidik anak-anak dan remaja dapat mengambil peran membantu remaja mengisi waktu luangnya dengan kegiatan positif. Sekolah dapat memfasilitasi dengan mengaktifkan kegiatan ekstrakurikuler di sekolah sehingga setelah jam sekolah usai siswa terhindar dari melakukan aktivitas yang mengarah pada kenakalan (Dazeva \& Tarmidi, 2012). Sekolah perlu memberikan kesempatan melaksanakan kegiatan-kegiatan nonakademik melalui perkumpulan penggemar olahraga sejenis, kesenian, dan lainnya untuk membantu remaja menyelesaikan tugas perkembangannya (Ali \& Asrori, 2008).

Kegiatan ekstrakurikuler dapat mencegah siswa melakukan tindakan yang menjurus kepada hal-hal yang negatif. Setelah pulang sekolah atau waktu liburan, remaja menghabiskan waktu di sekolah bersama dengan kelompok teman sebaya yang dibimbing oleh guru pembina ekstrakurikuler. Melalui kegiatan ekstrakurikuler, siswa diajarkan keterampilan teknis, disiplin, kerjasama, kepemimpinan dan nilai-nilai lain yang bermanfaat bagi perkembangan remaja. Aktif dalam kegiatan ekstrakurikuler dapat memperkecil peluang siswa untuk bergabung dengan teman-teman sebaya yang melakukan aktivitas negatif.

Untuk mengungkap permasalahan, peneliti memilih tempat di SMP Negeri 3 Way Jepara Kabupaten Lampung Timur karena memiliki berbagai macam kegiatan ekstrakulikuler. Selain itu, muncul banyaknya kasus seperti perkelahian, meminta uang secara paksa, melempar batu sampai bibirnya sobek, membuat kelompok genk, meletakkan sekumpulan lebah di pundak siswa lain, bakar-bakaran di kelas, mengambil bola dengan merusak lemari, menusuk pantat siswa lain dengan jarum jahit, serta berbagai bentuk perilaku agresifitas siswa baik yang terjadi di dalam maupun di luar sekolah menjadi alasan peneliti untuk memilih sekolah tersebut sebagai tempat penelitian. Penelitian ini akan melihat perbedaan perilaku agresif antara siswa aktif dan tidak aktif dalam kegiatan ekstrakurikuler di SMP Negeri 3 Way Jepara. Hipotesis penelitian adalah tidak ada perbedaan perilaku agresif siswa yang aktif mengikuti ekstrakurikuler dengan siswa yang tidak aktif mengikuti kegiatan ekstrakurikuler.

\section{METODE}

Penelitian ini merupakan penelitian kuantitatif non eksperimental. Penelitian ini bertujuan untuk mengetahui seberapa besar perbedaan agresivitas siswa yang aktif dengan yang tidak aktif dalam mengikuti kegiatan ekstrakurikuler. Penelitian ini 
menggunakan pendekatan kuantitatif, karena dalam menganalisis data menggunakan data-data numerikal/angka yang diolah dengan metode statistik, setelah diperoleh hasilnya, kemudian dideskripsikan dengan menguraikan kesimpulan yang didasari oleh angka yang diolah dengan metode statistik tersebut.

Penelitian ini menggunakan metode statistik deskriptif inferensial. Berdasarkan data hasil pengukuran terhadap sampel, peneliti memiliki gambaran mengenai sampel kemudian menggunakan statistik inferensial untuk menarik kesimpulan mengenai karakteristik populasi melalui karakteristik yang dimiliki oleh sampel penelitian.

Variabel penelitian yang digunakan adalah agresifitas siswa/remaja. Variabel penelitian ini mencakup dimensi agresifitas secara fisik dan verbal. Secara konseptual agresifitas adalah bentuk perilaku yang bertujuan untuk menyakiti atau merugikan orang lain dalam bentuk tindakan fisik maupun verbal. Agresifitas fisik pada remaja adalah berkelahi, memukul, melukai, dan merusak. Sedangkan agresivitas dalam bentuk verbal yaitu makian, mengejek, membantah, dan berbohong.

Batasan operasional untuk perilaku agresif adalah skor total yang diperoleh oleh subyek dari hasil pengolahan alat ukur perilaku agresif pada masa remaja. Makin tinggi skor yang diperoleh, maka semakin agresif perilakunya. Semakin rendah skor yang diperoleh berarti semakin tidak agresif.

Penelitian ini dilakukan di SMP Negeri 3 Way Jepara yang berlokasi di Jl. Tubagus Sanaja Desa Sumber Marga, Way Jepara, Kabupaten Lampung Timur Provinsi Lampung. Waktu penelitian dilaksanakan pada semester genap tahun ajaran 2017/2018 tepatnya pada bulan Februari 2018 sampai dengan April 2018.

Populasi penelitian yaitu siswa kelas VIII dan Kelas IX siswa SMP Negeri 3 Way Jepara. Jumlah siswa kelas VIII sebanyak 93 siswa dan kelas IX 87 siswa, sehingga total populasi sebesar 180 siswa. Untuk menentukan sampel digunakan teknik. Sampel diambil dengan cara Disproportionate Stratified Random Sampling, sehingga diperoleh sampel penelitian siswa yang aktif mengikuti kegiatan ekstrakurikuler dengan jumlah keseluruhan adalah 124 siswa, dan 56 siswa tidak aktif pada kegiatan ektrakurikuler.

Pembuatan instrumen ukur agresivitas didasarkan pada batasan konseptual, batasan operasional, dimensi yang telah ditentukan sebelumnya. Pengukuran kuesioner agresivitas menggunakan method of summated rating dari skala Likert. Skala ini terdiri dari beberapa butir pernyataan dengan lima nilai sikap, yaitu sangat setuju (SS), setuju (S), ragu-ragu (R), tidak setuju (TS), sangat tidak setuju (STS). Penilaian butir yang favourable atau butir positif bergerak dari angka 5-1, sedangkan butir yang unfavourable atau butir negatif bergerak dari angka 1-5.

Teknik statistik yang digunakan dalam menganalisis data adalah teknik statistik uji beda ( $t$ - test), dengan bantuan program SPSS versi 16.00 (Hartono, 2009). Uji beda merupakan uji pasangan yaitu uji perbedaan rerata antara dua kelompok.

\section{HASIL DAN PEMBAHASAN}

\section{Uji Normalitas}

Uji normalitas dilakukan untuk menguji apakah sampel berasal dari populasi yang terdistribusi normal atau tidak. Analisis statistik untuk ujinormalitas menggunakan uji Kolmogorov-Smirnov satu sampel (onesample Kolmogorov-Smirnov test) yang dilakukan 
dengan program SPSS 16.0. Distribusi yang akan diuji normalitasnya adalah semua kelompok. Setelah dilakukan perhitungan uji normalitas dari data siswa yang aktif mengikuti kegiatan ekstrakurikuler dan yang tidak aktif mengikuti kegiatan ekstrakurikuler diperoleh hasil pada Tabel 1.

Tabel 1. Data Uji Normalitas

\begin{tabular}{lll}
\hline Data & $\mathrm{P}$ & Kesimpulan \\
\hline Aktif dalam Kegiatan Ekstrakurikuler & 0.100 & Data berdistribusi normal \\
\hline $\begin{array}{l}\text { Tidak Aktif dalam Kegiatan } \\
\text { Ekstrakurikuler }\end{array}$ & 0.200 & Data berdistribusi normal \\
\hline
\end{tabular}

Menurut Triton (2005) persyaratan data disebut normal pada uji Kolmogorov-Smirnov jika taraf signifikansi atau probabilitas $p>0,05$. Data yang diperoleh dari perilaku agresif siswa yang aktif dan yang tidak aktif mengikuti kegiatan ekstrakurikuler seperti yang ditunjukkan pada Tabel 4 di atas, terlihat bahwa perilaku agresif siswa yang aktif dan yang tidak aktif mengikuti kegiatan ekstrakurikuler memiliki taraf signifikansi atau probabilitas (p) lebih dari 0,05 ini artinya data perilaku agresif siswa yang aktif dan yang tidak aktif mengikuti ekstrakurikuler berdistribusi normal.

\section{Uji Homogenitas}

Uji homogenitas bertujuan untuk mengetahui apakah sampel berasal dari varians yang sama atau tidak. Pada penelitian ini, uji homogenitas dilakukan melalui uji- $F$ dengan menggunakan program SPSS 16.0. Hasil analisis data perilaku agresif siswa yang aktif dan yang tidak aktif mengikuti kegiatan ekstrakurikuler dapat dilihat pada Tabel 2.

Tabel 2. Data Uji Homogenitas

\begin{tabular}{lll}
\hline Data & P & Kesimpulan \\
\hline Aktif dalam Kegiatan Ekstrakurikuler dan Tidak & 0.148 & Homogen \\
Aktif dalam Kegiatan Ekstrakurikuler & & \\
\hline
\end{tabular}

Menurut Triton (2005) sampel penelitian dapat dikatakan berasal dari populasi yang homogen jika harga probabilitas lebih besar dari 0,05 $(p>0,05)$. Berdasarkan Tabel 5, probabilitas perilaku agresif siswa yang aktif dan yang tidak aktif mengikuti kegiatan ekstrakurikuler terlihat lebih dari 0,05 artinya data perilaku agresif siswa yang aktif dan yang tidak aktif mengikuti kegiatan ekstrakurikuler memiliki varians yang homogen.

\section{Diskusi}

Penelitian ini bertujuan untuk mengetahui ada tidaknya perbedaan perilaku agresif siswa yang aktif dan yang tidak aktif mengikuti kegiatan ekstrakurikuler di SMP Negeri 3 Way Jepara Kabupaten Lampung Timur. Berdasarkan tujuan tersebut, maka penelitian ini merupakan metode penelitian komparatif dengan menggunakan metode survei. Setelah semua data diperoleh dalam penelitian, diolah dan dianalisis dengan uji $t$ didapatkan perbedaan perilaku agresif siswa yang aktif mengikuti kegiatan ekstrakurikuler dengan siswa yang tidak aktif mengikuti kegiatan ekstrakurikuler di SMP Negeri 3 Way Jepara Kabupaten Lampung Timur, dan perilaku agresif siswa yang aktif mengikuti ekstrakurikuler lebih rendah dibandingkan dengan siswa yang tidak aktif mengikuti kegiatan ekstrakurikuler di SMP Negeri 3 Kabupaten Lampung Timur. SMP 
Negeri 3 Way Jepara memiliki 13 ekstrakurikuler, yaitu: Olimpiade Fisika,Olimpiade Biologi,Olimpiade Matematika, Olimpiade IPS, LPIR, English Club, Baca Tulis Al Quran/Seni Kaligrafi, Seni Tari, Bola Volly, Badminton, Marching Band, Pramuka, Futsal. Pelaksanaan 13 ekstrakurikuler di SMP Negeri 3 Way Jepara tidak hanya mengembangkan fisik, tetapi juga mengembangkan nilai atau sikap karakter dan sikap sosial termasuk didalamnya mengembangkan emosi mental yang sehat. Adanya waktu tambahan diluar jam khusus sekolah ini juga menyebabkan siswa bisa lebih mengembangkan sikap sosialnya terhadapa teman yang lain.

Berbeda halnya dengan siswa yang tidak aktif mengikuti kegiatan ekstrakurikuler, meskipun siswa mendapatkan mata pelajaran di jam sekolah, namun kegiatan tersebut masih terfokus pada bagaimana materi pelajaran tersampaikan dan banyaknya waktu yang digunakan pada jam sekolah tidak sebanyak pada jam kegiatan ekstrakurikuler. Hal ini menyebabkan perilaku agresif siswa yang tidak aktif mengikuti kegiatan ekstrakurikuler lebih tinggi dibandingkan siswa yang tidak aktif mengikuti kegiatan ekstrakurikuler.

Kegiatan ekstrakurikuler merupakan salah satu kegiatan positif untuk mengisi waktu luang remaja. Pengisian waktu luang dengan baik dengan cara yang sesuai dengan umur remaja, masih merupakan masalah bagi kebanyakan remaja. Kebosanan, segan untuk melakukan apa saja merupakan fenomena yang sering dijumpai (Monks,2002). Sekolah mengambil peran untuk membantu siswa mengisi waktu luangnyadengan kegiatan positif melalui kegiatan ekstrakurikuler. Selain untuk mengisi waktu luang, partisipasi dalam kegiatan ekstrakurikuler dapat meningkatkan kepemilikan (sense of belonging) siswa terhadap sekolah, sehingga menurunkan tingkat bolos sekolah yang dilakukan siswa (Kombarakaran,2002).

Pengisian waktu luang dengan kegiatan positif dan produktif seperti kegiatan ekstrakurikuler dapat memperkecil peluang terbentuknya tingkah laku agresif (Tarigan \& Andayani, 2008). Kegiatan ekstrakurikuler dapat meningkatkan keterampilan interpersonal remaja. Melalui kegiatan ekstrakurikuler remaja menjalin hubungan interpersonal dengan teman sebaya anggota ekstrakurikuler yang diikuti, senior dan pembina ekstrakurikuler. Bagi remaja yang memiliki kompetensi interpersonal rendah, afiliasi dalam kegiatan ekstrakurikuler dapat meningkatkan penerimaan sosial dan popularitas, menurunkan alienasi sosial, mengembangkani dentitas sosial dan menurunkan perilaku antisosial (Eder \& Parker dalam Mahoney,2003). Kesadaran banyak manfaat yang bisa diperoleh dari kegiatan ekstrakurikuler akan meningkatkan minat siswa terhadap kegiatan ekstrakurikuler.

Minat mengikuti kegiatan ekstrakurikuler merupakan kecenderungan siswa untuk mengikuti kegiatan akademik yang diselenggarakan sekolah di luarjam pelajaran. Remaja yang memiliki minat yang tinggi dalam kegiatan ekstrakurikuler menguasai keterampilan intelektual dan konsep yang penting bagi kecakapan sosial (Hurlock, 2002). Intensi untuk berperilaku adalah kecenderungan individu untuk berperilaku tertentu (Ajzen \& Fishbein, 1997).

Seperti telah dinyatakan di atas bahwa kegiatan ekstrakurikuler dapat membentuk perilaku agresif karena dalam kegiatan ekstrakurikuler terdapat nilai-nilai empati seperti, kerjasama, tolong-menolong, saling menghargai dan sportif. Jadi jelaslah penelitian 
tentang perbedaan perilaku agresif siswa yang aktif dan yang tidak aktif mengikuti kegiatan ekstrakurikuler lebih rendah yang mengikuti kegiatan ekstrakurikuler.

\section{SIMPULAN}

Terdapat perbedaan perilaku agrasif siswa SMP Negeri 3 Way Jepara Kabupaten Lampung Timur yang aktif mengikuti kegiatan ekstrakurikuler dengan siswa yang tidak aktif mengikuti ekstrakurikuler. Perilaku agresif siswa yang aktif mengikuti kegiatan ekstrakurikuler lebih rendah $(p=0.100)$ dibandingkan siswa yang tidak aktif mengikuti kegiatan ekstrakurikuler $(p=0.200)$ dan $p$ lebih dari 0,05 ini artinya data perilaku agresif siswa yang aktif dan yang tidak aktif mengikuti ekstrakurikuler berdistribusi normal.

Penelitian ini menemukan bahwa perilaku agresif siswa SMP Negeri 3 Way Jepara Kabupaten Lampung Timur yang aktif mengikuti kegiatan ekstrakurikuler lebih rendah dibandingkan siswa yang tidak aktif mengikuti kegiatan ekstrakurikuler. Oleh karena itu disarankan agar siswa mengikuti kegiatan ekstrakurikuler secara menyeluruh pada semua siswa, karena kegiatan ekstrakurikuler itu mempengaruhi perilaku agresif bagi siswa di dalam kehidupan bermasyarakat dan sekolah. Kegiatan ekstrakurikuler agar efektif harus ditunjang oleh guru yang mempunyai keterampilan di bidang ektrakurikuler yang memadai, sehingga nantinya bisa menularkan ilmu dan pengetahuannya.

Perlu penelitian lebih lanjut tentang perilaku agresif siswa yang dihubungkan dengan keaktifan kegiatan ekstrakurikuler secara umum, sehingga kemampuan guru untuk membentuk manusia seutuhnya dapat dioptimalkan. Penelitian tersebut dibangun oleh pengembangan instrumen dan metode penelitian agar hasil yang diperoleh dapat maksimal.

\section{REFERENSI}

Ajzen, I., \& Fishbein, M. (1997). Beliefs, attitude and behavioral, an introduction to theory and research. Boston: Addison Wesley Publishing.

Ali, M., \& Asrori, M. (2008). Perkembangan peserta didik. Jakarta: Bumi Aksara.

Dazeva, V., \& Tarmidi. (2012). Perbedaan Kecerdasan Emosional Siswa Ditinjau dari Jenis Kegiatan Extrakurikuler. Psikologia: Jurnal Pemikiran dan Penelitian Psikologi, 7(2), 8192.

Hartono. (2009). SPSS 16.0: Analisis data statistika dan penelitian. Yogyakarta: Pustaka Pelajar.

Hurlock, E. B. (2002). Psikologi perkembangan. Suatu pendekatan sepanjang rentang kehidupan. Edisi kelima. Jakarta: Erlangga.

Kombarakaran, F. A. (2002). Effects of social capital and adolescent extracurricular activities on school truancy (Doctoral dissertation, The Ohio State university). 
Krahe, B. (2005). The social psychology of aggresion (Perilaku agresif). Jakarta : Erlangga.

Mahoney, J. L., Cairns, B. D., \& Farmer, T. W. (2003). Promoting interpersonal competence and educational success through extracurricular activity participation. Journal of Educational Psychology, 95(2), 409-418.

Majid, A. (2009). Perencanaan pembelajaran. Bandung: Remaja Rosdakarya.

Myers, D. G. (2002). Social psychology. 7th Edition. New York: McGraw-Hill Education.

Monks, F. J., Knoers, A. M. P., \& Haditono, S. R. (2002). Psikologi perkembangan pengantar dalam berbagai bagiannya. Yogyakarta: Gadjah Mada University Press.

Sarwono, S. W. (2005). Psikologi remaja. Jakarta: Raja Grafindo.

Schneider, B. H. (1991). A comparison of skill-building and desensitization strategies for intervention with aggressive children. Aggressive Behavior, 17(6), 301-311.

Siegel, J., \& Welsh, B. (2011). Juvenile delinquency the core. California: Wadsworth.

Tarigan, M., \& Andayani, B. (2008). Hubungan antara pemanfaatan waktu luang dengan kreativitas pada remaja. Insight, 1(3), 1-12.

Triton, P. B. (2005). SPSS 13.0. Terapan riset statistik parametrik. Yogyakarta: Penerbit Andi.

Verlaan, P., \& Schwartzman, A. E. (2002). Mother's and father's parental adjustment: Links to externalizing behavior problems in sons and daughters. International Journal of Behavioral Development, 26(3), 214-224. 